conducted experiment of the same kind, namely, the late Dr. Bateson's experiment (posthumously published from his notes by Sir Daniel Hall) on 'bolting' in sugar beets and mangolds. On an average, about 5 per cent of the plants in a field of sugar beets bolt, that is to say, they throw up a stem and set seed during their first year, so that the roots are denuded of sugar and worthless. The rest behave as biennials. Mangolds show a similar phenomenon. It was known that early sowing promotes bolting. Now, Bateson, we may assume, started out with the hypothesis that bolting may be due to internal or external causes. So, instead of sowing mangolds in the open in April, he sowed them under glass in December or January, and planted them out in April. Thus any plant with an inherent tendency to bolt was given the fullest opportunity to do so. Sutton's Prize Globe mangold gave only 2 bolters out of 390 when sown in April. But when sown in December, 8 out of 19 bolted. The 11 non-bolters were used for seed, and none of their progeny bolted, even when sown in January. However, some seedlings from this family were subjected to severe temptation to bolt by sowing in December. Ten out of 136 (a much smaller proportion) bolted ; but 213 of the progeny of the non-bolters refused to bolt when sown in January. In the case of sugar beet, the proportion of bolters was greater, and four generations were needed to eliminate the habit.
Bateson also made the converse experiment of trying to establish a race which always bolted. He did not get any appreciable increase of bolting when he selected the progeny of plants which had bolted as the result of early sowing. But by sowing seed of 12 plants out of 312 which had bolted when sown in April, he got 41 per cent of bolters. All this is entirely intelligible on the theory that bolting, in so far as it is an acquired character, is not inherited. If Dürken had bred from the pupæ which refused to turn green even in orange light, he would no doubt have been able to eliminate the tendency to turn green; and if he had bred from those which turn green in ordinary light, he would presumably have obtained a more striking change in the next generation than was actually found. In order to prove the Lamarckian theory, it would be necessary either to start with a pure line or not to practise selection. Harrison, who worked with the turnip white butterfly, Pieris rapa, which normally gives about 20 per cent of green pupæ, obtained more striking effects than Dürken, as he only appears to have eliminated 7 per cent in one generation and 5 per cent in the next, and yet obtained 31 pupæ, all green, in normal daylight. While Harrison's case is thus far stronger than Dürken's, it cannot be regarded as conclusive unless similar results are obtained without selection, either artificial or natural.

(To be continued.)

\title{
The Transport Problem in the United States
}

$\mathrm{I}^{\mathrm{N}}$ $\mathrm{N}$ the century and a half which has elapsed since the American steam-boat pioneers, Fitch and Rumsey, began their experiments on the Delaware and Potomac rivers, transport in the United States has undergone many remarkable changes. From the work of those pioneers, in the course of years, came a magnificent fleet of river steamers; her engineers next gave the country the most extensive railway system in the world; while to-day the automobiles are so numerous that there is one for every five of the population, and transport by air is making rapid progress.

America is what it is largely because of its transport, without which its prairies would still be uncultivated and its mines unexploited. One of the landmarks in the history of that transport was May 10, 1869, when the last spike-a golden one-was driven in the railway which connected the Atlantic coast with the shores of the Pacific. On that occasion Philadelphia rang the old Liberty Bell, New York fired a hundred guns, Buffalo sang "The Star-Spangled Banner", and there was even a thanksgiving service in Trinity. There then seemed no end to the benefits to be gained from the railways, which to-day, by the irony of fate, are faced almost with bankruptcy.

Like our own railway system, that of the United States was built up entirely by private enterprise, and the present position of the railways is much the same as our own; some think it is somewhat more complex. What that position is, and what remedies are suggested so that the railways can continue to fulfil their part in the national economy, are well stated in three contributions printed in the first issue for the current year of the Proceedings of the American Philosophical Society. The three papers are entitled: (1) "The Railroad Situation : Some Suggestions as to the Way Out"; (2) "A Way for the Railways to Keep Out after they are Out "; and (3) "Co-ordination as a 'Way-out' of the Transportation Crisis" - the respective authors of which are Dr. E. R. Johnson, Mr. A. B. Johnson, and Mr. G. L. Wilson. Of the three papers, the first is much the longest and gives a record of all the factors of the problem.

The United States railway system has some 250,000 miles of track, and the rolling stock includes about 67,000 locomotives, 57,000 passenger cars, and $2,500,000$ freight cars, the results of the development of a hundred years. The public roads include $3,000,000$ miles of highways, of which some 700,000 miles are surfaced and about 128,000 miles are mainly of concrete. About 50,000 miles of streets are constructed or rebuilt annually, the expenditure on which reaches $2,000,000$ dollars.

The number of automobiles of all kinds registered in the United States at the end of 1931 reached the astonishing figure of $23,042,840$, the result of thirty years' development; and the number of companies engaged in freight traffic services runs into thousands. There are no complete statistics of the freight carried by motor vehicles, but not only are 
fruit, vegetables, and live stock now conveyed by road, but also such things as coal and cotton. Of the $4,000,000$ bales of cotton grown in Texas in $1930,1,200,000$ reached the ports by motor vehicles. But severe as is the inroad made on the freight traffic of the railroads by motor wagons, still more severe is that due to the private motor car and the motor buses. In 1920 the passenger earnings of American railroads were nearly 21 per cent of their total operating revenues, but in 1930 this figure had fallen to 13.8 per cent, and the showing for 1931 was even worse.

Added to the competition from the roads is that due to the carriers by water, for inland and coastwise traffic. At the time the Panama Canal Act of 1912 was passed, several railroad companies had steamship lines on the Great Lakes and on the Pacific and Atlantic seaboards. By that Act, however, the companies were prohibited the use of the Canal for vessels owned by them, and other restrictions were placed on their maritime activities. At the close of the War, too, the United States possessed a large surplus of ships. Many of these were sold at a low figure and placed in service, while the Government itself entered the business of inland water transportation. The schemes have never paid their way, and, says Dr. Johnson, "it is hard to justify the continuance of business operation on this basis by the Government in competition with private enterprise ".

Traffic has not only been leaving the rails for the roads and waterways, but also for underground pipelines for distributing oil, natural gas, and gasoline. Formerly nearly all petroleum was sent by freight cars, and it involved a large tonnage. In 1929 only 4.5 per cent of the production was transported by rail. There are now 100,000 miles of crude oil pipelines in the United States, 65,000 miles of pipelines for the distribution of natural gas, and in 1931 there were also 3800 miles of gasoline pipelines. The rapid increase in the use of oil and gas has had a marked effect on the coal output of the country, and it has been estimated that in 1929 natural gas was substituted for about $77,500,000$ tons of bituminous coal.

As to civil aviation in the United States, a recent return shows that American air transport companies now operate over routes with a total mileage of 51,000 miles, and the machines cover a total distance of 150,000 miles every twenty-four hours.

The problem of co-ordinating the great and varied transportation services of the United States, it will thus be seen, is a very complex one. It is one dealt with by Dr. Johnson and Mr. Wilson in their respective papers, both of which are worthy of the attention of the authorities in Great Britain. In reviewing the constructive and corrective measures required, Dr. Johnson mentions the reduction of unprofitable train services, the operation by the railways of both passenger and freight motor services, a reduction in the competition among the railways themselves, the consolidation or grouping of the railways into a limited number of systems, the co-ordination of rail, road, water, and air services, and the regulation of all transport agencies by the Government, according to a sound and equitable national policy. What co-ordination means and how it can be effected is dealt with fully by Mr. Wilson, who says: "The trend towards coordination has proceeded to the point that we can predict that the great railroads, steamship companies, electric railways, and other specialised carriers will tend to become transportation companies ... offering a variety of transportation services to shippers and travellers that will supply the needs and fit the pocket-books of their patrons".

\section{Polar Lights *}

\section{By Prof. S. Chapman, F.R.S.}

\begin{abstract}
MANY of the principal facts concerning the I polar lights, or aurora, have long been known. For example, John Dalton, the great chemist, who observed the lights carefully for many years, and thought deeply upon them, was well aware of their close connexion with the earth's magnetism : as shown by their occurrence mainly in regions centred at the magnetic (rather than the geographical) poles, by their tendency to be extended in the direction transverse to the magnetic meridian, by the near agreement between the direction of auroral rays and the local direction of a freely poised magnetised needle, and by their parallelism, in time of occurrence and in intensity, with magnetic disturbances or storms. His ideas as to their height, on which Cavendish had made careful measurements, were also in general accord with modern determinations.
\end{abstract}

Modern observations of auroræ have advanced * Substance of a lecture delivered at the annual general meeting of
the British Science Guild on May 25 .

No. 3266 , VoL. 129] our knowledge chiefly by establishing the height and situation with incontrovertible accuracy, by the methods of Størmer and his followers ; and by the interpretation of the beautifully coloured auroral light, with the aid of the spectroscope and the great body of modern knowledge concerning atomic and molecular spectra.

Much remains to be done before the full fruits of the study of the auroral spectrum are garnered, but two main facts are established: a large part of the spectrum consists of bands due to singly ionised nitrogen molecules, while the famous green line, a standing challenge to spectroscopists for many decades, has been shown by McLennan to be emitted by neutral atomic oxygen; he, his colleagues, and others have traced the line in detail to its source in a particular transition occurring in the oxygen atom. Through the initiative of another active investigator of the auroral spectrum, Vegard, the Rockefeller Foundation has instituted an auroral observatory, maintained by the Norwegian Govern- 